\title{
Distribusi Spasial Dan Struktur Komunitas Plankton Di Daerah Teluk Penerusan, Kabupaten Buleleng
}

\author{
Ni Made Dewi Damayantia*, I Gede Hendrawan, Elok Faiqoha \\ aProgram Studi Ilmu Kelautan, Fakultas Kelautan dan Perikanan, Universitas Udayana, Kampus UNUD Bukit Jimbaran, Bali 80361, Indonesia
}

*Penulis koresponden. Tel.: +62-812-368-929-97

Alamat e-mail: dewidamayanti717@yahoo.com

Diterima (received) 14 September 2016;disetujui (accepted) 19 Juni 2017; tersedia secara online(available online) 23 Juni 2017

\begin{abstract}
Research spatial distribution and community structure of plankton in the Penerusan bay has been done on 22 February 2016.Plankton samples were taken at 17 stations using the Horizontal haul. The results obtained by the group of phytoplankton of the most widely found are from class Bacillariophyceae with the abundance of species composition percentage of $77 \%$ and the group most zooplankton were found came from class Maxillopoda with the percentage of the species composition of $85 \%$. Highest abundance of phytoplankton found in abundance station 5 , while the highest abundance of zooplankton found in abundance station 4. Index values diversity, uniformity and dominance of phytoplankton that is $1,06,0.40$ and 0.11 while the index value of diversity, uniformity and dominance zooplankton are $0.52,0.40$ and 0.34 . Results of the spatial distribution of phytoplankton abundance scattered in the middle of the bay towards the outside while the spatial distribution of zooplankton abundance spread from the south of the bay towards the middle of the bay and to the north of the bay Forwarding. Water quality in Penerusan Bay of physicists chemical parameters such as temperature obtained ranged from 31.1 to $32,5{ }^{\circ} \mathrm{C}$, average brightness obtained $87 \%$, turbidity obtained ranges between 0,73 to $2.62 \mathrm{ntu}$, dissolved oxygen (DO) obtained ranged from 6 to $8.3 \mathrm{mg} / 1$, the degree of acidity $(\mathrm{pH})$ obtained ranged from 7.17 to 8.04 , salinity obtained ranged from 31-35 ppt, nitrate values obtained ranged from 0.60 to $1.83 \mathrm{mg} / \mathrm{l}$ and phosphate values obtained ranged from 0.10 to $0.78 \mathrm{mg} / \mathrm{l}$.
\end{abstract}

Keywords:spatial distribution;community structure;plankton

\begin{abstract}
Abstrak
Penelitian distribusi spasial dan struktur komunitas plankton di Teluk Penerusan telah dilakukan pada tanggal 22 februari 2016. Sampel plankton di ambil di 17 stasiun dengan menggunakan metode Horizontal haul. Hasil yang diperoleh yaitu kelompok fitoplankton yang paling banyak di temukan berasal dari kelas Bacillariophyceae dengan persentase komposisi kelimpahan jenis sebesar $77 \%$ dan kelompok zooplankton yang paling banyak di temukan berasal dari kelas Maxillopoda dengan persentase komposisi jenis sebesar $85 \%$. Kelimpahan fitoplankton tertinggi di temukan pada stasiun 5 sedangkan kelimpahan zooplankton tertinggi di temukan pada stasiun 4 . Rata-rata nilai indeks keanekaragaman, keseragaman dan dominansi fitoplankton yaitu 1,06, 0.40 dan 0.11 sedangkan nilai indeks keanekaragaman, keseragaman dan dominansi zooplankton yaitu $0.52,0.40$ dan 0.34 . Hasil distribusi spasial kelimpahan fitoplankton tersebar di tengah-tengah Teluk kearah luar sedangkan distribusi spasial kelimpahan zooplankton tersebar dari selatan teluk kearah tengah teluk lalu ke arah utara Teluk Penerusan. Kualitas perairan di Teluk Penerusan dari parameter fisika- kimia yaitu suhu yang diperoleh berkisar antara $31,1-32,5{ }^{\circ} \mathrm{C}$, kecerahan rata-rata yang diperoleh $87 \%$, kekeruhan yang diperoleh berkisar antara 0,73-2,62 ntu, oksigen terlarut (DO) yang diperoleh berkisar antara $6-8,3 \mathrm{mg} / \mathrm{l}$, derajat keasaman $(\mathrm{pH})$ yang diperoleh berkisar antara 7,17 - 8,04,salinitas yang diperoleh berkisar antara 31,1-35 ppt, nilai nitrat yang diperoleh berkisar antara $0,604-1,826 \mathrm{mg} / \mathrm{l}$ dan nilai fosfat yang diperoleh berkisar antara 0,098 - 0,777 mg/l.
\end{abstract}

Kata Kunci:distribusi spasial;struktur komunitas;plankton 


\section{Pendahuluan}

Indonesia memiliki sumberdaya hayati, khususnya didaerah pesisir dan lautan. Salah satu sumberdaya hayati yang mempunyai peranan penting dalam ekosistem laut adalah plankton. Plankton adalah salah satu parameter biologi yang dipengaruhi oleh beberapa parameter dan merupakan rantai makanan yang sangat penting dalam menunjang kehidupan organisme lainnya.

Plankton merupakan biota yang beragam di laut. Plankton disebut juga disebut makluk (tumbuhan atau hewan) yang hidupnya mengapung, mengambang atau melayang di perairan. Plankton memiliki peranan penting di perairan. Plankton disini bersifat autotrof yang memiliki kemampuan merubah hara anorganik menjadi bahan organic (Usman dkk.,2013). Plankton disini dibagi menjadi dua yaitu fitoplankton dan zooplankton.

Fitoplankton disebut juga plankton nabati atau tumbuhan yang hidup mengapung atau melayang dalam laut. Fitoplankto merupakan organisme yang berperan sebagai produsen utama (primary producer). Fitoplankton dapat juga digunakan sebagai indikator untuk mengetahui kualitas dan kesuburan suatu perairan (Yuliana, 2015).Zooplankton adalah plankton hewani yang memiliki peranan yang penting di ekosistem. Zooplankton berperan sebagai konsumen primer penghubung antara fitoplankton dan konsumen tingkat 1 pada rantai makanan (Hasanah dkk., 2014). Selain itu juga zooplankton dapat digunakan sebagai indikator polusi perairan (Faiqoh dkk., 2015).

Teluk Penerusan merupakan salah satu wilayah perairan yang terletak Kecamatan Gerogak Kabupaten Buleleng, Bali. Luas perairan Teluk Penerusan adalah 877 Ha. Aktifitas yang ditemui di sekitar wilayah perairan Teluk Penerusan adalah kegiatan budidaya laut dengan media keramba jaring apung. Terdapat 20 buah keramba jaring apung yang masih aktif dipergunakan oleh masyarakat sebagai mata pencarian. Keramba jaring apung yang terdapat di wilayah Teluk Penerusan, memiliki potensi penambahan zat hara ke perairan yang dihasilkan oleh sisa-sisa pakan ikan buatan dan feses ikan dari hasil budidaya. Meningkatnya zat hara ke perairan akan mempengaruhi kelimpahan fitoplankton dan zooplankton di perairan tersebut. Di dekat Teluk Penerusan juga terdapat tambak yang pengambilan dan pembuangan limbahnya dilakukan dalam satu tempat yang sama dengan jarak tertentu dalam satu wilayah perairan, selain itu di sebelah selatan Teluk Penerusan sedang dibangun villa sebagai tempat wisata. Untuk melihat penyebaran secara spasial dari fitoplankton dan zooplankton dapat digunakan analisis spasial dengan sistem informasi geografis (SIG). Analisis spasial dengan sistem informasi geografis (SIG) telah banyak dimanfaatkan untuk kajian sumberdaya perairan.

Beberapa penelitian yang memanfaatkan SIG untuk kajian sumberdaya perairan yaitu penelitian mengenai hubungan antara distribusi fitoplankton dengan kualitas perairan di Selat Alas, Kabupaten Sumbawa, Nusa Tenggara Barat oleh Radiarta (2013)dan penelitian mengenai distribusi spasial dan temporal biomassa fitoplankton (klorofil-a) dan keterkaitannya dengan kesuburan perairan estuary sungai Brantas,Jawa timur oleh Arifin (2009). Kajian mengenai kelimpahan fitoplankton dengan kualitas perairan telah dilakukan di Teluk Jakarta (Yuliana dkk, 2012). Namun belum adanya kajian mengenai keterkaitan plankton secara spasial dan strukrur komunitas di TelukPenerusan membuat penelitian ini penting untuk dilakukan dengan tujuannya mengetahui distrubusi spasial dan struktur komunitas plankton sehingga penelitian ini dapat digunakan sebagai informasi dasar pengelolaan lingkungan untuk pemantauan kondisi perairan dan keperluan budidaya perikanan.

\section{Metode Penelitian}

\subsection{Waktu dan Lokasi Penelitian}

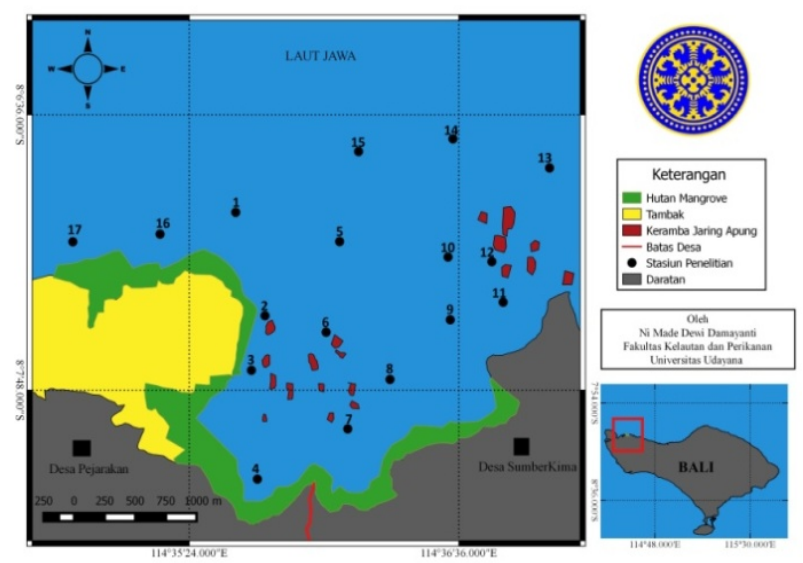

Gambar 1. Lokasi Penelitian di Teluk Penerusan, Buleleng, Bali 
Penelitian ini dilaksanakan pada tanggal 22 Februari 2016.Lokasi Penelitian ini berada di daerah Teluk Penerusan, Buleleng, Bali. Penelitian ini dilakukan dengan pengambilan data pada 17 stasiun. Penentuan stasiun pengamatan dilakukan dengan metode purposive sampling. Berikut merupakan Gambar lokasi penelitian (Gambar 1).

\subsection{Alat dan Bahan}

Alat dan bahan yang akan digunakan dalam penelitian ini tersajikan secara lengkap pada Tabel 1.

Tabel 1

Alat dan Bahan Penelitian

\begin{tabular}{|c|c|c|}
\hline Alat /Bahan & Kegunaan & Satuan \\
\hline Planktonet & $\begin{array}{l}\text { Menyaring plankton di } \\
\text { perairan }\end{array}$ & $\begin{array}{l}\text { Mesh size } \\
\text { jaring } 80 \\
\text { mikrometer }\end{array}$ \\
\hline Botol & Menyimpan Sampel & $100 \mathrm{ml}$ \\
\hline Sampel & Plankton & \\
\hline $\mathrm{pH}$ meter & Mengukur pH dan suhu & ${ }^{0} \mathrm{C}$ \\
\hline DO meter & $\begin{array}{l}\text { Mengukur DO di } \\
\text { Perairan }\end{array}$ & $\mathrm{Mg} / \mathrm{L}$ \\
\hline Sechii Disk & Mengukur Kecerahan & $\mathrm{M}$ \\
\hline Refrakto & Mengukur Salinitas & Ppt \\
\hline Mikroskop & Melihat sampel plankton & - \\
\hline Sedgewick & Media untuk & $\mathrm{Mm}$ \\
\hline Rafter & $\begin{array}{l}\text { penempatan sampel } \\
\text { plankton }\end{array}$ & \\
\hline Pipet tetes & $\begin{array}{l}\text { Untuk mengambil } \\
\text { sampel plankton dari } \\
\text { botol }\end{array}$ & - \\
\hline GPS & $\begin{array}{l}\text { Menunjukkan kordinat } \\
\text { stasiun pengambilan } \\
\text { sampel }\end{array}$ & $\begin{array}{l}\text { Derajat, } \\
\text { menit, detik }\end{array}$ \\
\hline Turbidity & Mengukur Kekeruhan & NTU \\
\hline Meter & Perairan & \\
\hline $\begin{array}{l}\text { Botol } \\
\text { sampel air }\end{array}$ & $\begin{array}{l}\text { menyimpal sampel air } \\
\text { untuk analisis nitrat dan } \\
\text { fosfat }\end{array}$ & - \\
\hline Formalin $4 \%$ & $\begin{array}{l}\text { Untuk mengawetkan } \\
\text { sample plankton }\end{array}$ & - \\
\hline Lugol & $\begin{array}{l}\text { Untuk memberi warna } \\
\text { pada sample plankton }\end{array}$ & - \\
\hline
\end{tabular}

\subsection{Analisis Data Penelitian}

\subsubsection{Kelimpahan Plankton}

Perhitungan Kelimpahan Plankton dilakukan dengan menggunakan metode sub-sample (Greenberg et al., 1980) dengan satuan $\mathrm{Ind} / \mathrm{m}^{3}$, rumus perhitungan kelimpahan plankton seperti pada persamaan 1 .
$\mathrm{N}=\mathrm{nx} \frac{\mathrm{Vt}}{\mathrm{Vo}} \times \frac{\mathrm{Acg}}{\mathrm{Aa}} \times \frac{1}{\mathrm{Vd}}$

dimana $\mathrm{N}$ merupakan kelimpahan plankton dengan satuan Ind $/ \mathrm{m}^{3}$. N merupakan jumlah individu fitoplankton dan zooplankton yang telah diindentifikasi. Vt adalah volume air sampel yang tersaring dalam botol dengan jumlah $100 \mathrm{ml}$. Vo merupakan volume air pada Sedgwick-Rafter Counting Cell sebanyak $1 \mathrm{ml}$. Acg adalah luasan Sedgwick-Rafter Counting Cell yang diamati. Aa merupakan luasan petak pada Sedgwick-Rafter Counting Cell. Dan Vd merupakan volume air yang tersaring dengan satuan $\mathrm{m}^{3}$.Untuk mencari Vd dapat digunakan rumus dibawah ini :

$\mathrm{Vd}=\mathrm{R} . \mathrm{a} \cdot \mathrm{p}$

dimana $\mathrm{R}$ merupakan Jumlah rotasi baling-baling flowmeter. a merupakan Luas mulut jaring (m2) dan $\mathrm{p}$ adalah Koefisien kalibrasi flowmeter (panjang kolom air yang ditempuh untuk satu rotasi baling- baling flowmeter).

\subsubsection{Struktur Komunitas Plankton}

a. Indeks Keanekaragaman

Indek keanekaragaman menunjukkan keberadaan jenis dan merupakan ciri khas struktur komunitas. Menurut Basmi (1995) perhitungan indeks keanekaragaman menggunakan persamaan 3.

$\mathrm{H}^{\prime}=-\sum_{\mathrm{i}-1}^{\mathrm{s}}(\mathrm{Pi})(\log \mathrm{Pi})$

dimana $\mathrm{H}^{\prime}$ merupakan indeks keanekaragaman. S merupakan jumlah genus dan $\mathrm{Pi}$ merupakan perbandingan jumlah genus ke-i dengan jumlah individu total yang telah ditemukan kolom air yang ditempuh untuk satu rotasi baling - baling (flowmeter).

Menurut Basmi (1995) kisaran dari nilai keanekaragaman dapat diklasifikasikan sebagai berikut :Jika $\mathrm{H}^{\prime}<1$ dapat diklasifikasikan bahwa Keanekaragaman plankton kecil dan kestabilan komunitas plankton rendah. Jika $\mathrm{H} 1<\mathrm{H}^{\prime}<3$ diklasifikasikan bahwa keanekaragaman sedang, kestabilan komunitas sedang dan jika $\mathrm{H}^{\prime}>3$ diklasifikasikan bahwa keanekaragaman Tinggi kestabilan komunitas tinggi.

b. Indeks Keseragaman

Untuk mengetahui seberapa besar kesamaan penyebaran jumlah individu tiap jenis plankton 
digunakan indeks keseragaman, yaitu dengan cara membandingkan indeks keanekaragaman dengan indeks maksimum. Menurut Basmi(1995)rumus perhitungan Indeks Keseragaman sebagai berikut:

$\mathrm{E}=\frac{\mathrm{H}^{\prime}}{\log _{2} \mathrm{~S}}=\frac{\mathrm{H}^{\prime}}{\mathrm{H}_{\text {maks }}}$

dimana E merupakan Indeks keseragaman (Evenness index). $\mathrm{H}^{\prime}$ merupakan Indeks keanekaragaman dan $\mathrm{S}$ adalah Jumlah genus.

Menurut Basmi (1995) Penggolongan kondisi komunitas biota dapat diklasifikasikan sebagai berikut :Jika $\mathrm{E}<0.4$ dapat diklasifikasikan bahwa Keseragaman plankton pada ekosistem rendah. Jika 0,4<E< 0,6 dapat diklasifikasikan bahwa keseragaman plankton pada ekosistem sedang sedangkan dan jika $\mathrm{E}>0.6$ dapat diklasifikasikan bahwa Keseragaman plankton pada ekosistem Tinggi

\section{c. Indeks Dominasi}

Untuk menGambarkan jenis plankton yang paling banyak ditemukan dapat diketahui dengan menghitung indeks dominansi. Rumus Indeks Dominansi menurut (Odum, 1998) adalah sebagai berikut :

$C=\sum_{i=1}^{s}\left(\frac{n i}{N}\right)^{2}=\sum_{i=1}^{S} P i^{2}$

dimana C merupakan Indeks dominansi, ni merupakan nilai dari setiap genus (jumlah jenis individu ke-i). $\mathrm{N}$ merupakan nilai total dari seluruh genus (jumlah individu total yang telah ditemukan) dan Pi merupakan Perbandingan jumlah individu jenis ke-i dengan jumlah individu total yang telah ditemukan.

Menurut Odum (1998) menyatakan bahwa kisaran nilai dominan dapat diklasifikasikan sebagai berikut :Dimana jika $0<\mathrm{C} \leq 0,5$ dapat diklasifikasikan bahwa dominasi plankton pada ekosistem rendah. Jika $0,50<\mathrm{C}<0,75$ dapat diklasifikasikan bahwa dominansi plankton pada ekosistem sedang dan jika $0,75<\mathrm{C}<1$ dominansi plankton pada ekosistem tinggi.

\subsubsection{Analisis Distribusi Spasial}

Hasil analisis sampel plankton yang telah diperoleh kemudian dianalisis secara spasial dengan menggunakan software QGIS yang merupakan software open source. Untuk memperoleh data spasial dari data stasiun diperlukan interpolasi. Metode interpolasi yang digunakan adalah metode interpolasi inverse distance weighting (IDW). Inverse Distance Weighting didasarkan pada asumsi nilai-nilai terdekat yang berkontribusi lebih terhadap nilainilai interpolasi dari pengamatan yang jauh. Keuntungan InverseDistance Weighting adalah metode ini intuitif dan efisien.

Analisis komponen utama merupakan suatu teknik statistik untuk mengubah dari sebagian besar variabel asli yang digunakan dan saling berkorelasi satu dengan yang lainnya menjadi satu set variabel baru yang lebih kecil dan tidak berkorelasi. Analisis Komponen Utama (Principal Component Analysis) ini merupakan metode statistik interdependen yang bertujuan mempresentasikan informasi maksimum yang terdapat dalam suatu matriks data dalam bentuk grafik. Matriks data ini terdiri dari stasiun pengamatan sebagai individu statistik pada baris dan parameter fisika kimia perairan sebagai variabel kuantitatif pada kolom. Analisis komponen utama pada penelitian ini menggunakan software Statistika 13.

\section{Hasil dan Pembahasan}

\subsection{Komposisi Jenis plankton di Teluk Penerusan, Kabupaten Buleleng}

Penelitian mengenai distribusi spasial dan struktur komunitas plankton ini dilakukan di daerah Teluk Penerusan, Desa Penjarakan, Kabupaten Buleleng. Pada Penelitian ini, dari 17 stasiun pengamatan yang diambil ditemukan 38 genus fitoplankton dan 7 Genus Zooplankton. berikut merupakan grafik komposisi jenis plankton di Teluk Penerusan, Kabupaten Buleleng.

\subsubsection{Komposisi Jenis Fitoplankton di Teluk} Penerusan, Kabupaten Buleleng.

Komposisi jenis fitoplankton yang ditemukan pada lokasi penelitian di Teluk Penerusan sejumlah 35 genus yang terdiri dari 5 kelas yang digolongkan dalam kelas Bacillariophyceae sebanyak 25 genus, kelas Cyanophyceae sebanyak 6 genus, kelas Dinophyceae sebanyak 2 genus, Kelas Haptophyceae sebanyak 1 genus, dan kelas Prymnesiophyceae sebanyak 1 genus. Genus yang paling banyak di temukan berasal dari genus Nitzchia Sedangkan genus yang paling sedikit 
ditemukan berasal dari genus Chroococus dan Halosphaera.

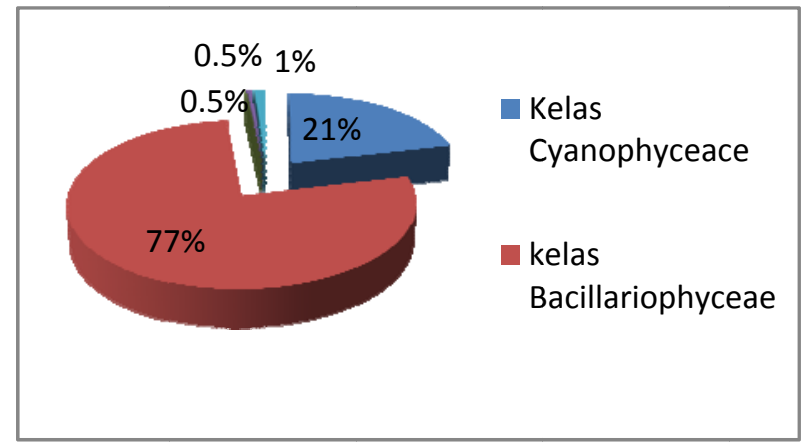

Gambar 2. Grafik Komposisi Jenis Fitoplankton di Teluk Penerusan.

3.1.2 Komposisi Jenis Zooplankton di perairan Teluk Penerusan, Kabupaten Buleleng.

Komposisi jenis zooplankton terdiri dari 7 genus yang berasal dari 2 kelas yaitu kelas Maxillopoda sebanyak 6 genus dan Kelas Malacostraca sebanyak 1 genus. Kelas Maxillopoda atau copepoda yang ditemukan pada penelitian ini berasal dari genus Cyclops, genus Calanus, genus Paracalanus, genus Arcatia, genus Corycaeus dan Nauplii dan Kelas Malacostraca yang ditemukan berasal dari genus mysi.

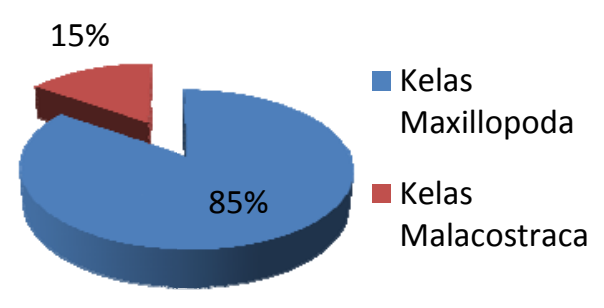

Gambar 3. Grafik Komposisi Jenis Zooplankton

3.2 Kelimpahan dan Distribusi Spasial Plankton di Teluk Penerusan, Kabupaten Buleleng

Hasil kelimpahan plankton yang diperoleh selanjutnya di interpolasi untuk menghasilkan sebaran spasial kelimpahan plankton di Teluk Penerusan. Peta distribusi spasial kelimpahan plankton yang diperoleh kemudian dibagi menjadi dua yaitu peta distribusi spasial kelimpahan fitoplankton dan peta distribusi spasial kelimpahan zooplankton. Berikut merupakan hasil kelimpahan fitoplankton dan zooplankton di daerah Teluk Penerusan, Kabupaten Buleleng.
Tabel 2

Tabel Kelimpahan Plankton di daerah teluk Penerusan Buleleng.

\begin{tabular}{ccc}
\hline \multicolumn{3}{c}{ Kelimpahan } \\
\hline Stasiun & Fitoplankton & Zooplankton \\
\hline 1 & 1565 & 80 \\
2 & 735 & 38 \\
3 & 1678 & 156 \\
4 & 1244 & 217 \\
5 & 1914 & 47 \\
6 & 1895 & 179 \\
7 & 693 & 99 \\
8 & 1565 & 38 \\
7 & 1664 & 57 \\
8 & 1513 & 94 \\
9 & 1391 & 104 \\
10 & 646 & 52 \\
11 & 434 & 52 \\
12 & 490 & 85 \\
13 & 1056 & 189 \\
14 & 580 & 61 \\
15 & 712 & 85 \\
16 & 1565 & 80 \\
17 & 735 & 38 \\
\hline
\end{tabular}

Tabel 2 menunjukkan bahwa kelimpahan fitoplankton tertinggi berada pada stasiun 5 dengan jumlah kelimpahan 1.914 ind $/ \mathrm{m}^{3}$. Nilai kelimpahan fitoplankton terendah berada pada stasiun 13 dengan jumlah kelimpahan $434 \mathrm{ind} / \mathrm{m}^{3}$. Dengan rata-rata nilai kelimpahan fitoplankton $1.163 \mathrm{ind} / \mathrm{m}^{3}$ dan standar deviasi yang diperoleh yaitu 520. Sedangkan hasil kelimpahan zooplankton menunjukkan kelimpahan terbesar berada pada stasiun 4 dengan kelimpahan mencapai $217 \mathrm{ind} / \mathrm{m}^{3}$ dan kelimpahan terkecil pada stasiun 2 dengan kelimpahan mencapai $38 \mathrm{ind} / \mathrm{m}^{3}$. Nilai rata-rata kelimpahan zooplankton yaitu 96 ind $/ \mathrm{m}^{3}$ dengan standar deviasi sebesar 56 .

3.2.1 Distribusi Spasial Kelimpahan Fitoplankton di Teluk Penerusan, Kabupaten Buleleng.

Pada Gambar 4 terlihat sebaran spasial kelimpahan fitoplankton tersebar dari bagian ditengah-tengah teluk penerusan ke bagian luar teluk. Konsentrasi terbesar kelimpahan 
fitoplankton berada pada bagian tengah teluk dan konsentrasi terkecil berada dibagian Timur laut dan barat laut Teluk Penerusan.

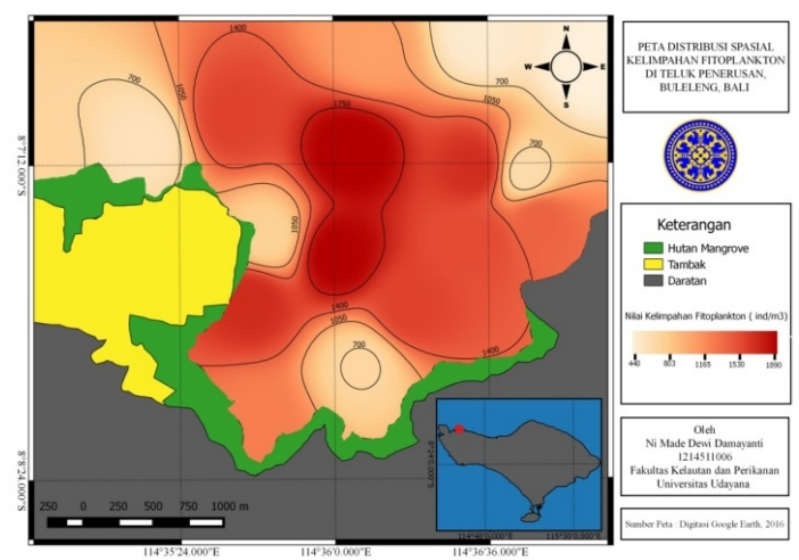

Gambar 4. Peta Distribusi spasial Kelimpahan Fitoplankton di Teluk Penerusan, Kabupaten Buleleng.

\section{Tabel 3}

Tabel Struktur Komunitas Fitoplankton di Teluk Penerusan, Buleleng

\begin{tabular}{cccc}
\hline \multicolumn{4}{c}{ Fitoplankton } \\
\hline \multirow{2}{*}{ Stasiun } & $\begin{array}{c}\text { Indeks } \\
\text { Keanekaragaman }\end{array}$ & $\begin{array}{c}\text { Indeks } \\
\text { Keseragaman }\end{array}$ & $\begin{array}{c}\text { Indeks } \\
\text { Dominansi }\end{array}$ \\
\hline 1 & 1.15 & 0.40 & 0.08 \\
2 & 1.01 & 0.37 & 0.12 \\
3 & 0.97 & 0.37 & 0.10 \\
4 & 1.06 & 0.38 & 0.11 \\
5 & 1.17 & 0.40 & 0.08 \\
6 & 1.07 & 0.39 & 0.11 \\
7 & 0.85 & 0.39 & 0.17 \\
8 & 1.01 & 0.38 & 0.13 \\
9 & 1.03 & 0.36 & 0.12 \\
10 & 1.11 & 0.38 & 0.10 \\
11 & 1.23 & 0.39 & 0.08 \\
12 & 1.12 & 0.40 & 0.10 \\
13 & 1.05 & 0.41 & 0.10 \\
14 & 0.95 & 0.40 & 0.13 \\
15 & 1.09 & 0.39 & 0.10 \\
16 & 1.02 & 0.40 & 0.12 \\
17 & 1.08 & 0.40 & 0.10 \\
\hline
\end{tabular}

3.2.2 Distribusi Spasial Kelimpahan zooplankton di Teluk Penerusan, Kabupaten Buleleng.

Gambar 5 memperlihatkan sebaran spasial kelimpahan zooplankton Kelimpahan zooplankton tersebar dari bagian selatan teluk yang berdekatan dengan daratan kemudian kebagian tengah teluk sampai ke bagian utara Teluk Penerusan. Konsentrasi kelimpahan zooplankton terbesar berada pada bagian selatan teluk dan konsentrasi kelimpahan zooplankton terkecil berada pada bagian barat laut teluk dan di timur laut Teluk.

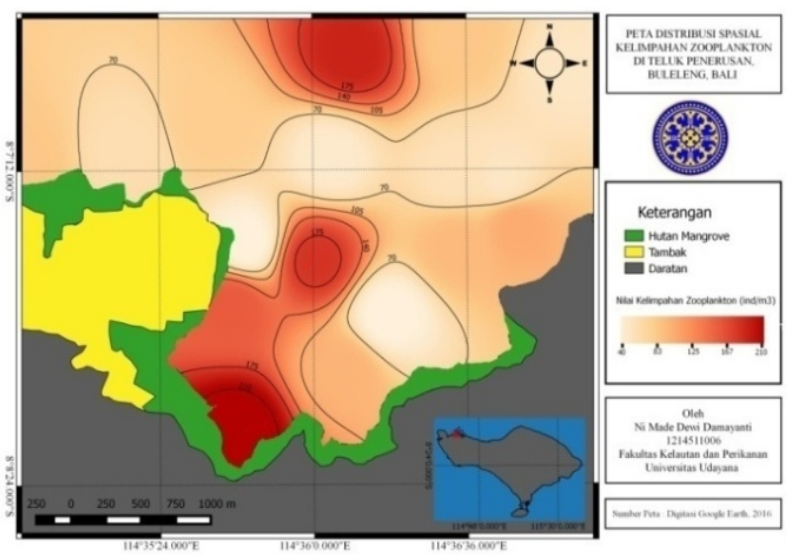

Gambar 5. Peta Distribusi spasial kelimpahan zooplankton di Teluk Penerusan, Kabupaten Buleleng.

\subsection{Struktur Komunitas Plankton di Teluk Penerusan, Kabupaten Buleleng}

Tabel 3 menunjukkan nilai indeks keanekaragaman fitoplankton yang diperoleh berkisar antara $0,85-1,23$. Rata-rata indeks keanekaragaman yaitu 1,06 dengan standard deviasi sebesar 0,08. Indeks keanekaragaman terbesar berada di stasiun 11 dan indeks keanekaragaman terkecil berada di stasiun 7 . Indeks keseragaman fitoplankton yang diperoleh berkisar antara 0,37 - 0,41. Rata-rata indeks keanekaragaman yaitu 0,40 dengan standard deviasi sebesar 0,01. Indeks keanekaragaman terbesar berada di stasiun 13 dan indeks keanekaragaman terkecil berada di stasiun 9. Indeks dominansi fitoplankton yang diperoleh berkisar antara 0,08 - 0,17. Rata-rata indeks dominansi yaitu 0,11 dengan standard deviasi sebesar 0,02. Indeks dominansi terbesar berada di stasiun 7 dan indeks dominansi terkecil berada di stasiun 11.

Tabel 4 menunjukkan nilai struktur komunitas zooplankton di Teluk Penerusan. Dimana, Indeks keanekaragaman zooplankton yang diperoleh berkisar antara 0.28 sampai 0,69 dengan rata-rata nilai indeks keanekaragaman 0,52. Standard deviasi pada indeks keanekaragaman zooplankton yaitu 0,13 . Indeks keanekaragaman terbesar berada di stasiun 15 dan 17 sedangkan indeks keanekaragaman terkecil berada di stasiun 9. Indeks keseragaman zooplankton yang diperoleh berkisar antara 0.32 sampai 0,43 dengan rata-rata nilai indeks keanekaragaman 0,40. Standar deviasi 
pada indeks keseragaman zooplankton yaitu 0,03. Indeks dominansi zooplankton yang diperoleh berkisar antara 0,21 - 0,56. Rata-rata indeks dominansi yaitu 0,34 dengan standard deviasi sebesar 0,11 . Indeks dominansi terbesar berada di stasiun 9 dan indeks dominansi terkecil berada di stasiun 15 dan 17.

\subsection{Parameter Kualitas Perairan di Teluk Penerusan, Kabupaten Buleleng}

Tabel 5 merupakan hasil kualitas perairan yang didapat pada 17 stasiun penelitian di daerah Teluk Penerusan, Kabupaten Buleleng. Hasil pengukuran suhu dalam penelitian ini berkisar $31,3^{\circ} \mathrm{C}$ sampai $32,5^{\circ} \mathrm{C}$ dengan rata-rata suhu $31,8^{\circ} \mathrm{C}$. Standar deviasi yang diperoleh dari suhu yaitu 0,37. Hasil pengukuran suhu yang tertinggi terdapat pada stasiun 4 dan hasil pengukuran suhu yang terendah terdapat pada stasiun 2 .

Hasil pengukuran DO di perairan Teluk Penerusan berkisar antara $6,4 \mathrm{mg} / \mathrm{L}$ sampai 8,3 $\mathrm{mg} / \mathrm{L}$. Dengan rata-rata nilai DO yang diperoleh $7,34 \mathrm{mg} / \mathrm{L}$. Standar deviasi DO yaitu 0,71 . Nilai oksigen terlarut tertinggi berada pada stasiun 5 dan nilai oksigen terlarut yang terendah pada stasiun 2.
Tabel 4

Tabel Struktur Komunitas Zooplankton di Teluk Penerusan, Kabupaten Buleleng

\begin{tabular}{cccc}
\hline \multicolumn{4}{c}{ Zooplankton } \\
\hline \multirow{2}{*}{ Stasiun } & $\begin{array}{c}\text { Indeks } \\
\text { Keanekaragaman }\end{array}$ & $\begin{array}{c}\text { Indeks } \\
\text { Keseragaman }\end{array}$ & $\begin{array}{c}\text { Indeks } \\
\text { Dominansi }\end{array}$ \\
\hline 1 & 0.49 & 0.35 & 0.40 \\
2 & 0.47 & 0.43 & 0.35 \\
3 & 0.45 & 0.32 & 0.42 \\
4 & 0.60 & 0.33 & 0.34 \\
5 & 0.29 & 0.42 & 0.52 \\
6 & 0.62 & 0.35 & 0.30 \\
7 & 0.59 & 0.42 & 0.27 \\
8 & 0.29 & 0.41 & 0.53 \\
9 & 0.28 & 0.40 & 0.56 \\
10 & 0.60 & 0.43 & 0.26 \\
11 & 0.56 & 0.41 & 0.29 \\
12 & 0.58 & 0.42 & 0.27 \\
13 & 0.58 & 0.42 & 0.27 \\
14 & 0.65 & 0.40 & 0.25 \\
15 & 0.69 & 0.43 & 0.21 \\
16 & 0.44 & 0.40 & 0.38 \\
17 & 0.69 & 0.43 & 0.21 \\
\hline
\end{tabular}

Hasil pengukuran $\mathrm{pH}$ pada penelitian ini berkisar antara 7,71 sampai 8,04 . Rata- rata nilai $\mathrm{pH}$ yaitu 7,69 dengan standar deviasi yang diperoleh 0,25 . Nilai $\mathrm{pH}$ terbesar berada pada

Tabel 5

Tabel hasil kualitas perairan di perairan Teluk Penerusan, Kabupaten Buleleng, Bali.

\begin{tabular}{ccccccccc}
\hline Stasiun & $\begin{array}{c}\text { DO } \\
(\mathrm{mg} / \mathrm{L})\end{array}$ & $\begin{array}{c}\text { Suhu } \\
\left(\mathrm{C}^{0}\right)\end{array}$ & $\mathrm{pH}$ & $\begin{array}{c}\text { Salinitas } \\
(\mathrm{ppt})\end{array}$ & $\begin{array}{c}\text { Kekeruhan } \\
(\mathrm{ntu})\end{array}$ & $\begin{array}{c}\text { Kecerahan } \\
(\%)\end{array}$ & $\begin{array}{c}\text { Nitrat } \\
(\mathrm{mg} / \mathrm{L})\end{array}$ & $\begin{array}{c}\text { Fosfat } \\
(\mathrm{mg} / \mathrm{L})\end{array}$ \\
\hline 1 & 6.4 & 31.5 & 7.7 & 35 & 2 & 100 & 1.82 & 0.59 \\
\hline 2 & 6 & 31.1 & 7.7 & 31 & 1.05 & 60 & 0.99 & 0.74 \\
\hline 3 & 7.5 & 32.1 & 7.5 & 29 & 1.71 & 100 & 0.92 & 0.30 \\
\hline 4 & 6.5 & 32.5 & 7.6 & 29 & 1.55 & 60 & 0.82 & 0.22 \\
\hline 5 & 8.3 & 32.4 & 8.0 & 33 & 0.73 & 41 & 0.60 & 0.40 \\
\hline 6 & 7.6 & 31.7 & 8.0 & 30 & 1.3 & 100 & 0.94 & 0.42 \\
\hline 7 & 7.9 & 31.3 & 8.0 & 31 & 2.13 & 94 & 0.63 & 0.47 \\
\hline 8 & 7.1 & 32.3 & 7.5 & 32 & 2.29 & 72 & 0.88 & 0.49 \\
\hline 9 & 6.9 & 31.9 & 7.7 & 35 & 1.9 & 100 & 0.90 & 0.22 \\
\hline 10 & 7.3 & 32.2 & 7.5 & 33 & 1 & 81 & 0.74 & 0.09 \\
\hline 11 & 6.9 & 32.1 & 7.5 & 30 & 1.51 & 66 & 0.81 & 0.33 \\
\hline 12 & 7 & 31.7 & 7.4 & 31 & 1.3 & 100 & 0.90 & 0.32 \\
\hline 13 & 6.9 & 31.8 & 7.1 & 35 & 1.38 & 100 & 0.90 & 0.29 \\
\hline 14 & 8 & 31.9 & 8.0 & 30 & 2.62 & 100 & 0.88 & 0.77 \\
\hline 15 & 7.8 & 32 & 8.0 & 30 & 1.64 & 100 & 0.99 & 0.27 \\
\hline 16 & 8.5 & 31.9 & 7.6 & 33 & 3.4 & 100 & 0.88 & 0.13 \\
\hline 17 & 8.2 & 31.7 & 7.6 & 31 & 1.98 & 100 & 0.74 & 0.16 \\
\hline
\end{tabular}


stasiun 14 dan nilai $\mathrm{pH}$ terkecil berada pada stasiun 13.

Hasil pengukuran salinitas di perairan Teluk Penerusan berkisar antara 29 - 35 ppt. Rata-rata nilai salinitas yang diperoleh yaitu 31,6 ppt dengan standar deviasi mencapai 2,02. Salinitas tertinggi berada pada stasiun 1, 9, 13 sebesar 35 ppt dan nilai salinitas terendah berada pada stasiun 3 dan 4 sebesar 29 ppt.

Hasil nilai kekeruhan yang diperoleh pada penelitian ini berkisar antara 0,73 sampai 3,4 ntu. Nilai kekeruhan tertinggi berada pada stasiun 16 dengan nilai kekeruhan sebesar 3,4 ntu dan nilai kekeruhan terendah berada pada stasiun 5 dengan nilai kekeruhan 0,73 ntu. Menurut Kep MENLH ni 51 tahun 2004 menetapkan baku mutu nilai kekeruhan bagi biota laut adalah < 5 ntu. Dari data yang didapat menunjukkan bahwa nilai kekeruhan dari semua stasiun pengamatan di Teluk Penerusan berada dalam kisaran yang masih normal dan sangat baik untuk menunjang proses kehidupan biota di dalamnya.

Perairan Teluk Penerusan memiliki kedalaman yang variatif namun relative dangkal. Kedalaman perairan di 17 stasiun pengamatan di Teluk penerusan berkisar antara 1 meter sampai 24 meter dengan tingkat kecerahan 40 sampai 100\%.Stasiun 5 memiliki kedalam perairan yang paling dalam sebesar 24 meter. Sedangkan perairan yang paling dangkal berada di stasiun 16. Tingkat kecerahan perairan rata-rata mencapai $88,6 \%$ dengan standar deviasi 19,3.

Hasil kekeruhan yang diperoleh di semua stasiun pada penelitian ini berkisar antara 0,73 sampai 3,4 ntu (Gambar 7) dengan rata-rata nilai kekeruhan 1,73. Nilai kekeruhan tertinggi berada pada stasiun 16 dan nilai kekeruhan terendah berada pada stasiun 5. Standar deviasi yang diperoleh dari nilai kekeruhan adalah 0,65.

Kandungan nilai nitrat pada perairan Teluk Penerusan berkisar antara 0, $604 \mathrm{mg} / \mathrm{L}$ sampai $1,826 \mathrm{mg} / \mathrm{L}$. rata-rata nilai nitrat yang diperoleh yaitu $0,9 \mathrm{mg} / \mathrm{L}$ dengan standar deviasi 0,26 . Nilai tertinggi dari kandungan nitrat berada pada stasiun 1 yaitu 1,826 mg/L. Kandungan nitrat terendah berada pada stasiun 5 dengan nilai 0,604 $\mathrm{mg} / \mathrm{L}$.

Kandungan fosfat yang didapat pada penelitian ini berkisar antara 0,098 mg/L sampai 0,743 mg/L. Rata-rata nilai fosfat yang diperoleh yaitu 0,36 $\mathrm{mg} / \mathrm{L}$ dengan standar deviasi sebesar 0,19.
Kandungan fosfat yang tertinggi berada di stasiun 14 dan nilai fosfat terendah berada di stasiun 10 .

\subsection{Analisis Komponen Utama di Teluk Penerusan, Kabupaten Buleleng}

Untuk mengetahui hubungan antara parameter fisika, kimia dengan biologi perairan (kelimpahan fitoplankton dan zooplankton) digunakan analisis komponen utama. Parameter fisika, kimia dan biologi yang perhitungkan yaitu : suhu, kekeruhan, kecerahan, oksigen terlarut (DO), Derajat keasaman $(\mathrm{pH})$, salinitas, nitrat, fosfat dan kelimpahan plankton. Hasil perhitungan analisis komponen utama terdiri atas akar ciri (eigenvalue), nilai kumulatif ragam dan matriks korelasi yang diperoleh dengan menggunakan software Statistica 13.

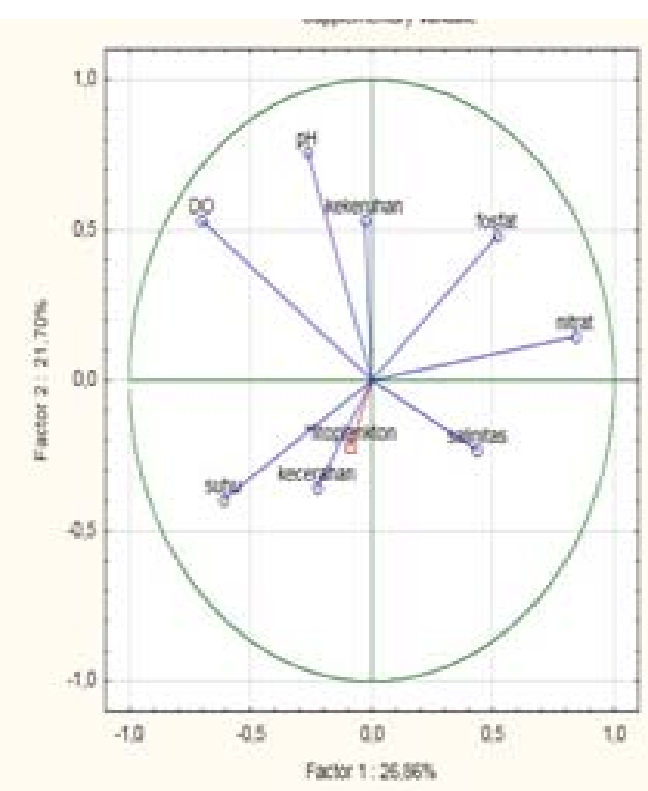

Gambar 6. Analisis komponen utama parameter fisika, kimia perairan dengan Kelimpahan Fitoplankton.

Sesuai dengan (Gambar 6) Analisis komponen utama pada 17 stasiun pengamatan menghasilkan dua sumbu penyusun komponen utama dengan kontribusi total mencapai 48,46\% yang berarti analisis komponen utama ini dapat menjelaskan data tersebut sampai dengan 48,46 \%. Sebagian besar informasi terpusat pada faktor 1, dimana sumbu ini menjelaskan 26,86\% dari ragam total, sedangkan faktor 2 menjelaskan 21,70 \% dari ragam total.

Hasil analisis komponen utama kelimpahan fitoplankton dapat dilihat pada Gambar 6.Hasil analisis komponen utama menunjukkan parameter 
fisika- kimia yang mempengaruhi kelimpahan fitoplankton adalah parameter kecerahan, kekeruhan dan $\mathrm{pH}$. Hal ini berdasarkan dari nilai faktor yang diperoleh, dimana kelimpahan fitoplankton dicirikan oleh faktor 2.Parameter fisika- kimia yang mencirikan faktor 2 adalah kecerahan, kekeruhan dan $\mathrm{pH}$.

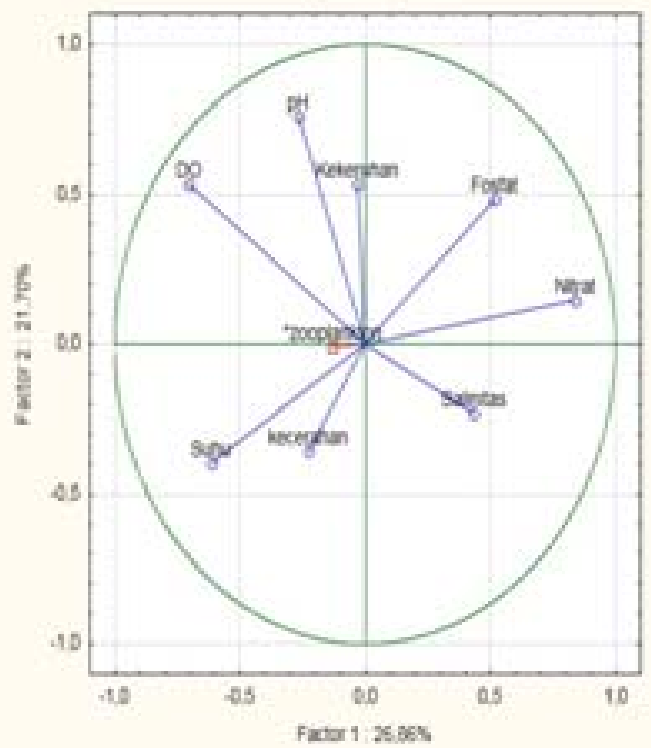

Gambar 7. Analisis komponen utama parameter fisika, kimia perairan dengan Kelimpahan Zooplankton.

Berikut merupakan Gambar hasil analisis komponen kelimpahan fitoplankton dan kelimpahan zooplankton dengan kualitas perairan. Dimana garis biru merupakan active (yang mempengaruhi) dan garis merah merupakan Suppl (dipengaruhi).

Sesuai dengan (Gambar 8) Analisis komponen utama pada 17 stasiun pengamatan menghasilkan dua sumbu penyusun komponen utama dengan kontribusi total mencapai 48,46\% yang berarti analisis komponen utama ini dapat menjelaskan data tersebut sampai dengan 48,46 \%. Sebagian besar informasi terpusat pada faktor 1, dimana sumbu ini menjelaskan 26,86\% dari ragam total, sedangkan faktor 2 menjelaskan 21,70 \% dari ragam total.

Hasil analisis komponen utama kelimpahan zooplankton dapat dilihat pada Gambar 8. Hasil menunjukkan parameter fisika-kimia yang mempengaruhi kelimpahan zooplankton adalah parameter DO, suhu, salinitas, nitrat dan fosfat. Hal ini berdasarkan dari nilai faktor yang diperoleh, dimana kelimpahan zooplankton dicirikan oleh faktor 1 dan parameter fisika- kimia yang mencirikan faktor 1 adalah suhu, salinitas, DO, nitrat dan fosfat.

Berikut merupakan hasil analisis komponen utama penyebaran stasiun penelitian berdasarkan hasil parameter fisika - kimia yang diperoleh pada 17 stasiun di Teluk Penerusan. Berdasarkan penyebaran titik pengamatan pada faktor 1 dan faktor 2 diperoleh adanya 4 pengelompokan titik pengamatan. Pada kuadran 1 penyebaran titik pengamatan didominasi oleh titik 9, 12, dan 13 . Kuadran 2 didominasi oleh titik 1 dan 2. Kuadran 3 didominasi oleh titik 5, 6, 7, 14, 16 dan 17 dan kuadran 4 didominasi oleh titik 3, 4, 8, 10 dan 11 .

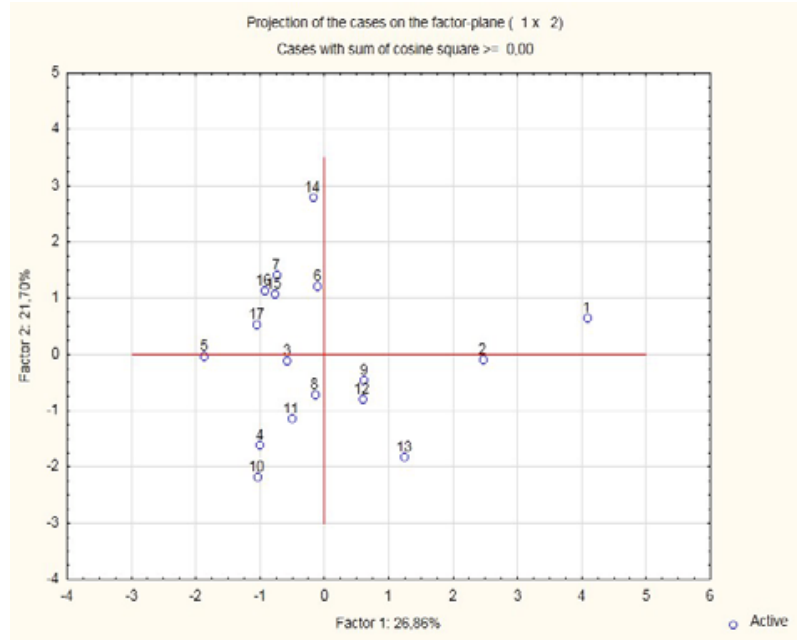

Gambar 8. Grafik Analisis Komponen Utama Penyebaran stasiun pengamatan berdasarkan parameter yang mempengaruhi.

Hasil komposisi jenis fitoplankton yang diperoleh menunjukkan persentase kelas yang terbesar berasal dari kelas Bacillariophyceae dengan persentase sebesar 77\%. Kelas Bacillariophyceae merupakan kelas pada fitoplankton yang memiliki sifat kosmopolit serta penyebarannya yang luas dan memiliki tingkat toleransi yang tinggi terhadap perubahan-perubahan faktor lingkungan.

Keberadaan kelas Bacillariophyceae yang paling banyak ditemukan pada suatu perairan merupakan hal umum yang terjadi di perairan laut. Kelas Bacillariophcyceae mempunyai komposisi yang tinggi dibanding kelas yang lain karena dapat tumbuh dengan cepat meskipun pada kondisi nutrient dan cahaya yang rendah dan juga kelas tersebut memiliki kemampuan regenerasi dan reproduksi yang lebih besar. Penelitian sama juga menemukan bahwa Kelas Bacillariophyceae, banyak ditemukan di perairan Teluk Sekotong dan Teluk Kodek, Lombok (Sutomo, 2013). Munthe 
dan Isnaini (2012) pada penelitian mengenai struktur komunitas dan sebaran fitoplankton di Perairan Sunsang, Sumatra Selatan juga memperoleh kelas dari fitoplankton yang banyak ditemukan berasal dari kelas Bacillariophyceae.

Genus yang jumlah individunya paling banyak ditemukan di Teluk Penerusan adalah Genus Nitzchia dengan jumlah yang ditemukan sebanyak 193 individu, dimana diketahui genus ini memiliki kemampuan pertumbuhan yang cepat. Menurut Odum (1998) Genus Nitzschia sp memiliki kemampuan pertumbuhan yang cepat, dimana laju pembelahan maksimum sekali pembelahan dalam waktu 10-12 jam.

Hasil komposisi jenis zooplankton yang diperoleh menunjukkan persentase kelas yang terbesar berasal dari kelas Maxillopoda dengan persentase $85 \%$ dan genus yang paling banyak ditemukan berasal dari genus Arcatia dengan jumlah 38 individu. Kelas Maxillopoda (copepoda) memiliki habitat hidup di air laut dan air tawar.

Kelas Maxillopoda juga memegang peranan penting dalam rantai makanan pada suatu ekosistem perairan. Sesuai dengan penelitian yang diperoleh di daerah Teluk Penerusan diindikasikan bahwa perairan Teluk Penerusan merupakan perairan yang produktif. Fitriya dan Lukman (2013) juga menyatakan bahwa perairan yang didominasi oleh kelompok Maxillopoda (copepod) dapat mengindikasikan keadaan perairan tersebut produktif. Penelitian yang dilakukan oleh Simanjuntak (2009) di Perairan Belitung Timur, Bangka Belitung juga menemukan jenis zooplankton yang banyak ditemukan berasal dari kelas Maxillopoda (copepoda).Mulyadi dan Sulistyo (2012) juga menemukan bahwa jenis zooplankton dari kelas Maxillopoda (copepoda) banyak ditemukan di Perairan Teluk Ambon.

Hasil kelimpahan fitoplankton yang diperoleh berkisar antara $1.914 \mathrm{ind} / \mathrm{m}^{3}-434 \mathrm{ind} / \mathrm{m}^{3}$. Nilai ratarata $1.163 \mathrm{ind} / \mathrm{m}^{3}$ Standar deviasi yang diperoleh yaitu 520,3. Kelimpahan fitoplankton tertinggi berada pada stasiun 5 dan stasiun 6 . Stasiun lain yang memiliki kelimpahan fitoplankton melebihi nilai rata-rata yaitu pada stasiun 1, 3, 4, 8, 9, 10 dan 15. Tingginya kelimpahan fitoplankton di beberapa stasiun diduga dikarenakan oleh faktor fisika-kimia di perairan. Salah satunya adalah faktor kecerahan, kekeruhan dan $\mathrm{pH}$. Dilihat dari Hasil kecerahan dan kekeruhan yang diperoleh di Teluk Penerusan menunjukkan kecerahan yang relative tinggi untuk perairan ini sedangkan nilai kekeruhan yang rendah memberikan masukan cahaya yang tinggi ke perairan sehingga fitoplankton dapat lebih cepat melakukan proses fotosintesis. Cahaya merupakan faktor penting bagi fitoplankton untuk melakukan fotosintesa yang sesuai dengan kebutuhannya (Sutomo, 2013). Intensitas cahaya pada stasiun penelitian bervariasi antara stasiun tetapi masih dalam batas toleransi alami. Hasil $\mathrm{pH}$ yang di temukan di Teluk Penerusan juga menunjukkan nilai yang sesuai untuk kehidupan fitoplankton.

Hasil kelimpahan ini juga didukung dari hasil analisis komponen utama kelimpahan fitoplankton, dimana parameter kualitas perairan yang mempengaruhi kelimpahan fitoplankton adalah kecerahan, kekeruhan dan $\mathrm{pH}$.

Pada Distribusi spasial kelimpahan fitoplankton, terlihat bahwa konsentrasi kelimpahan fitoplankton terbesar berada di tengah Teluk Penerusan kemudian penyebaran kelimpahan fitoplankton mengecil ke arah timur teluk, barat teluk dan selatan teluk. penyebaran kelimpahan fitoplankton terkecil berada di arah timur laut dan barat laut pada Teluk Penerusan. Sebaran spasial kelimpahan fitoplankton yang banyak ditemukan berada di dekat keramba jaring apung yang berada di bagian tengah teluk ,bagian timur teluk serta bagian selatan teluk. Diketahui bahwa keramba jaring apung dapat menyumbangkan bahan organik pada perairan.

Bahan organik tersebut berupa sisa pakan buatan dan feses ikan pada keramba jaring apung. bahan organic ini diduga dimanfaatkan oleh fitoplankton untuk berkembang sehingga kelimpahan fitoplankton menjadi banyak. Diketahui bahwa Perairan yang berdekatan dengan daerah budidaya memiliki potensi menerima masukan bahan organik dari sisa-sisa pakan dan feses ikan yang lebih besar. Bahan organik ini akan di manfaatkan fitoplankton untuk berkembang biak sehingga kelimpahan fitoplankton menjadi besar.

Hasil Kelimpahan zooplankton yang diperoleh berkisar antara $38 \mathrm{ind} / \mathrm{m}^{3}-217 \mathrm{ind} / \mathrm{m}^{3}$. Rata-rata nilai kelimpahan zooplankton yaitu 98 ind $/ \mathrm{m}^{3}$ dengan nilai standard deviasi sebesar 55,9. Kelimpahan zooplankton terbesar berada pada stasiun 4 . Stasiun lain yang memiliki kelimpahan zooplankton melebihi nilai rata-rata adalah stasiun 3, 6, dan 15. Kelimpahan zooplankton yang 
diperoleh diduga disebabkan oleh parameter fisika-kimia perairan dan ketersediaan makanan atau fitoplankton yang banyak. Nutrien atau zat hara merupakan zat - zat yang penting bagi kehidupan plankton. Salah satu nutrient tersebut adalah nitrat dan fosfat. Hasil nitrat dan fosfat yang diperoleh menunjukkan nilai rata-rata untuk hasil nitrat yaitu $0,9 \mathrm{mg} / \mathrm{L}$ dan rata-rata fosfat 0,36 $\mathrm{mg} / \mathrm{L}$. Kandungan nitrat dan fosfat di teluk penerusan menunjukkan bahwa nitrat dan fosfat baik untuk pertumbuhan fitoplankton. Fitoplankton yang tumbuh dengan baik menyebabkan ketersediaan makanan bagi zooplankton sehingga kelimpahan zooplankton menjadi banyak. Karena pada rantai makanan zooplankton berperan sebagai konsumen pertama yang memangsa produsen yaitu fitoplankton. Hubungan antara pemangsa dan yang dimangsa ini sesuai dengan theory of grazing.

Suhu juga menjadi salah satu faktor kelimpahan zooplankton banyak ditemukan di Teluk Penerusan. Hasil suhu yang diperoleh di Teluk Penerusan menunjukkan nilai yang sesuai untuk kehidupan zooplankton. Usman $d k k$ (2013) juga memperoleh kelimpahan plankton yang banyak pada kisaran suhu $30-35{ }^{\circ} \mathrm{C}$ di perairan Pulau Bangka, Minahasa Utara. Hasil ini juga didukung oleh hasil analisis komponen utama kelimpahan zooplankton di Teluk Penerusan. Hasil analisis komponen utama menunjukkan parameter fisika-kimia yang mempengaruhi kelimpahan zooplankton adalah suhu, DO, Salinitas, nitrat dan Fosfat.

Pada peta distribusi spasial kelimpahan zooplankton terlihat sebaran kelimpahan zooplankton terbesar berada pada barat daya teluk kemudian menyebar ke arah tengah teluk dan terakhir ke arah utara Teluk penerusan. Penyebaran diduga kelimpahan zooplankton ini berhubungan dengan sebaran kelimpahan fitoplankton. Dimana terlihat bahwa pada sebaran fitoplankton pada barat daya teluk cukup besar sehingga makanan bagi zooplankton tersedia dengan cukup, selain itu di bagian tengah teluk juga memiliki kelimpahan fitoplankton yang besar dan mencukupi kebutuhan makanan bagi zooplankton sehingga zooplankton dapat berkembang dengan baik. Peristiwa ini juga dapat disebut theory of grazing. Hal ini berdasarkan pada penemuan kuantitas zooplankton dan fitoplankton yang sama-sama melimpah di barat daya teluk, di tengah Teluk dan di utara Teluk Penerusan.
Struktur Komunitas fitoplankton menunjukkan bahwa nilai keanekaragaman di Teluk Penerusan menunjukkan nilai keanekaragaman sedang dengan kestabilan komunitas sedang, hal ini berdasarkan metode Basmi (1995). Arti dari indeks keanekaragaman sedang yaitu keanekaragaman jenis tergolong sedang (prima) dengan sebaran individu sedang dan kestabilan komunitas sedang. Nilai indeks keseragaman menunjukkan nilai keseragaman yang sedang. Hal ini berdasarkan Basmi (1995) dimana jika nilai indeks keseragaman 0,4 dinyatakan bahwa keseragaman jenis di wilayah tersebut sedang. Arti dari keseragaman sedang yaitu keseragaman organisme di perairan tersebut seimbang dan tidak terjadi persaingan baik makanan maupun tempat tinggal. Hasil indeks dominansi menunjukkan nilai dominansi rendah. Odum (1998) menyatakan jika nilai indeks dominansi kurang dari 0,5 dinyatakan bahwa dominansi jenis di wilayah tersebut rendah. Arti dari dominansi rendah yaitu tidak terdapat jenis fitoplankton yang mendominasi di perairan ini dan perairan ini dapat dikatakan masih baik untuk kehidupan fitoplankton.

Hasil Struktur komunitas fitoplankton menunjukkan bahwa perairan di Teluk Penerusan memiliki kondisi perairan stabil dan kondisi lingkungan yang baik. Terbukti dari nilai indeks keanekaragaman yang sedang dengan dominansi yang rendah artinya perairan tersebut masih baik untuk ditinggali oleh berbagai macam jenis fitoplankton. Terbukti dari hasil kualitas perairan yang diperoleh di Teluk Penerusan dimana untuk kecerahan dan kekeruhan perairan masih tergolong baik untuk kehidupan fitoplankton dalam melakukan fotosintesi. $\mathrm{pH}$ perairan yang diperoleh di Teluk Penerusan juga menunjukkan hasil yang baik untuk kehidupan fitoplankton.

Struktur komunitas zooplankton menunjukkan bahwa nilai keanekaragaman di Teluk Penerusan memiliki nilai keanekaragaman rendah dengan kestabilan komunitas rendah. Arti dari keanekaragaman rendah adalah tidak banyak jenis zooplankton yang hidup di perairan tersebut, terbukti dari hasil komposisi jenis zooplankton yang hanya menemukan 7 genus zooplankton di Teluk Penerusan.

Sedangkan nilai indeks keseragaman menunjukkan nilai keseragaman yang sedang. Arti dari keseragaman sedang yaitu keseragaman organisme di perairan tersebut seimbang dan tidak 
terjadi persaingan baik makanan maupun tempat tinggal dan indeks dominansi menunjukkan nilai yang sedang. Arti dari dominansi yang sedang yaitu terdapat jenis zooplankton yang mendominasi di perairan tersebut namun jumlah individunya masih sedang atau perbedaan jumlah individunya jenis yang mendominasi tidak terlalu besar dengan jenis lainnya. Sehingga dominansinya masih sedang. Dari hasil struktur komunitas zooplankton menunjukkan bahwa perairan di Teluk Penerusan memiliki kondisi perairan yang cukup stabil dan kondisi lingkungan yang cukup. Hal ini ditunjukkan dengan nilai keanekaragaman rendah dengan dominansi yang sedang. Sehingga dari hasil struktur komunitas plankton yang diperoleh mengindikasikan bahwa perairan Teluk Penerusan memiliki kondisi perairan yang cukup stabil untuk kehidupan plankton dan kondisi lingkungan yang baik. Terbukti dari hasil kualitas perairan, dimana suhu, DO dan salinitas yang diperoleh di Teluk Penerusan menunjukkan nilai yang baik bagi kehidupan zooplankton. Konsentrasi nitrat dan fosfat di perairan juga masih sesuai dengan pertumbuhan plankton di perairan.

Hasil analisis komponen utama kelimpahan fitoplankton menunjukkan bahwa parameter fisika - kimia yang mempengaruhi kelimpahan fitoplankton adalah kecerahan, kekeruhan dan $\mathrm{pH}$. Dimana diketahui bahwa kelimpahan fitoplankton lebih berkontribusi pada faktor 2 sehingga parameter fisika-kimia yang berkontribusi pada faktor 2 yaitu kecerahan, kekeruhan dan $\mathrm{pH}$. Hal ini terbukti dari nilai kekeruhan yang diperoleh kecil (Tabel 5) sehingga kecerahan perairan menjadi tinggi. Hal ini akan mempermudah fitoplankton untuk melakukan fotosintesis sehingga fitoplankton dapat tumbuh dengan baik. Sedangkan dari hasil $\mathrm{pH}$ yang di peroleh (Tabel 5) menunjukkan nilai $\mathrm{pH}$ perairan yang diperoleh sesuai untuk kehidupan fitoplankton.

Hasil analisis komponen utama kelimpahan zooplankton menunjukkan bahwa parameter fisika- kimia yang mempengaruhi kelimpahan zooplankton adalah suhu, DO, salinitas, nitrat dan fosfat. Dimana diketahui bahwa kelimpahan zooplankton lebih berkontribusi pada faktor 1 sehingga parameter fisika-kimia yang berkontribusi pada faktor 1 yaitu suhu, DO, salinitas, nitrat dan fosfat. Hal ini terbukti dari hasil suhu perairan yang diperoleh sesuai dengan kehidupan zooplankton (Tabel 5). Hasil nitrat dan fosfat juga menunjukkan bahwa konsentrasi nitrat (Tabel 5) dan konsentrasi fosfat (Tabel 5) yang diperoleh sesuai untuk kehidupan zooplankton. Untuk nilai DO (Tabel 5) dan Salinitas (Tabel 4) yang diperoleh sesuai dengan kehidupan zooplankton di perairan.

Hasil sebaran stasiun pengamatan (Gambar 8) kemudian diproyeksikan ke hasil analisis komponen utama parameter kualitas perairan (Gambar 6 dan 7). Terlihat bahwa hasil sebaran stasiun pengamatan dibagi atas 4 kelompok. Kelompok 1 terdapat 3 stasiun yaitu stasiun 9, 12 dan 13 dimana pada stasiun 9 berkontribusi pada faktor 1 sehingga memiliki ciri parameter yang mempengaruhi yaitu suhu, DO, salinitas, nitrat dan fosfat. Sedangkan stasiun 12 dan 13 berkontribusi pada faktor 2 sehingga memiliki ciri parameter yang mempengaruhi yaitu kecerahan, kekeruhan dan $\mathrm{pH}$. Kelompok 2 terdapat 2 stasiun yaitu stasiun 1 dan 2, dimana stasiun 1 dan 2 berkontribusi pada faktor 1 sehingga memiliki ciri parameter yang mempengaruhi yaitu suhu, DO, salinitas, nitrat dan fosfat. Pada kelompok 3 terdapat 6 stasiun yaitu stasiun 5, 6, 7, 14, 16 dan 17, dimana pada stasiun 5 dan 17 berkontribusi pada faktor 1 sehingga memiliki ciri parameter yang mempengaruhi yaitu oleh suhu, DO, salinitas, nitrat dan fosfat. Sedangkan stasiun $6,7,14$, dan 16 berkontribusi pada faktor 2 sehingga memiliki ciri parameter yang mempengaruhi yaitu kekeruhan, kecerahan dan $\mathrm{pH}$. Kelompok 4 terdapat 5 stasiun yaitu stasiun 3, 4, 8, 10 dan 11 . Dimana stasiun 3 berkontribusi pada faktor 1 sehingga memiliki ciri parameter yang mempengaruhi yaitu suhu, DO, salinitas, nitrat dan fosfat. Sedangkan stasiun 4, 8, 10, dan 11 berkontribusi pada faktor 2 sehingga memiliki cirri parameter yang mempengaruhi yaitu kecerahan, kekeruhan dan $\mathrm{pH}$.

\section{Simpulan}

Kesimpulan yang diperoleh dari hasil penelitian mengenai Distribusi Spasial dan Struktur Komunitas Plankton di Daerah Teluk Penerusan adalah kelimpahan Fitoplankton berkisar antara $434 \mathrm{ind} / \mathrm{m} 3$ - 1.914 ind/m3 sedangkan Kelimpahan zooplankton berkisar antara $38 \mathrm{ind} / \mathrm{m} 3$ - 217 ind/m3. Sebaran distribusi spasial kelimpahan fitoplankton berpusat di tengah-tengah Teluk Penerusan menuju ke daerah barat teluk dan Timur Teluk Penerusan, sedangkan sebaran 
distribusi spasial kelimpahan zooplankton tersebar di daerah barat daya Teluk Penerusan menyebar ke tengah teluk penerusan dan sampai ke mulut Teluk Penerusan di bagian Utara. Struktur komunitas fitoplankton dan zooplankton di Teluk Penerusan menyatakan bahwa perairan Teluk Penerusan memiliki kondisi perairan dalam keadaan cukup stabil dan kondisi lingkungan baik.

\section{Ucapan terimakasih}

Penulis mengucapkan terima kasih kepada seluruh pihak yang telah memberikan masukandan bimbingan dalam pembuatan jurnal ilmiah ini. Terimakasih yang sebesar - besarnya kepada Fakultas Kelautan dan Perikanan atas fasilitas yang telah diberikan. Kepada rekan - rekan dalam pengambian data dan penulis juga mengucapkan terimakasih kepada seluruh pihak yang sudah memberikan doa dan dukungannya.

\section{Daftar Pustaka}

Arifin, R. (2009). Distribusi Spasial dan Temporal Biomassa Fitoplankton (Klorofil-a) dan Keterkaitannya dengan Kesuburan Perairan Estuari Sungai Brantas, Jawa Timur. Skripsi. Bogor, Indonesia: Departemen Manajemen Sumberdaya Perairan, Fakultas Perikanan Dan Ilmu Kelautan, Institut Pertanian Bogor.

Basmi, J., (1995). Planktonologi : Produksi Primer. Bogor, Indonesia: Fakultas Perikanan Institut Pertanian Bogor.

Faiqoh, E., Ayu, I. P., Subhan, B., Syamsuni, Y. F., Anggoro, A. W., \& Sembiring, A. (2015). Variasi Geografik Kelimpahan Zooplankton di Perairan Terganggu, Kepulauan Seribu, Indonesia. Journal of Marine and Aquatic Sciences, 1(1), 19-22.

Fitriya, N., \& Lukman, M. (2013). Komunitas Zooplankton di Perairan Lamalera dan Laut Sawu, Nusa Tenggara Timur. Jurnal Ilmu dan Teknologi Kelautan Tropis, 5(1), 219-227.

Greenberg, A. E., Connors, J. J., Jenkins, D., \& Franson, M. A. H. (1980). Standard methods for the examination of water and waste water. (15 $5^{\text {th }}$ Edition). Washington, D.C., USA: American Public Health Association (APHA), the American Water Works Association (AWWA), and the Water Environment Federation (WEF).

Hasanah, A. N., Rukminasari, N., \& Sitepu, F. G. (2014). Perbandingan Kelimpahan dan Struktur Komunitas Zooplankton di Pulau Kodingareng dan Lanyukang, Kota Makassar. TORANI: Jurnal Ilmu Kelautan dan Perikanan, 24(1), 1-14.

Mulyadi, H. A. \& Sulistyo, I. (2012). Distribusi dan Kepadatan Plankton di Perairan Teluk Ambon. OmniAkuatika, 11(14), 28-40.

Munthe, Y. V., \& Aryawati, R. (2014). Struktur Komunitas dan Sebaran Fitoplankton di Perairan Sungsang Sumatera Selatan. Maspari Journal, 4(1), 122-130.

Odum, E. P. ( 1998). Dasar-dasar Ekologi. Edisi ke tiga. Diterjemahkan oleh Ir Tjahyono Samingan. Yogyakarta, Indonesia; Gajah Mada University Press.

Radiarta, I. N. (2012). Hubungan antara distribusi fitoplankton Dengan kualitas perairan di selat alas, Kabupaten Sumbawa, Nusa Tenggara Barat. Bumi Lestari, 13(2), 234-243.

Simanjuntak, M. (2009). Hubungan faktor lingkungan kimia, fisika terhadap distribusi plankton di perairan Belitung Timur, Bangka Belitung. Journal of Fisheries Sciences, 11(1), 31-45.

Sutomo, S. (2013). Struktur Komunitas Fitoplankton di Perairan Teluk Sekotong dan Teluk Kodek,Kabupaten Lombok. Jurnal Ilmu dan Teknologi Kelautan Tropis, 5(1), 131-144.

Usman, M. S., Kusen, J. D., \& Rimper, J. R. (2013). Struktur Komunitas Plankton Di Perairan Pulau Bangka Kabupaten Minahasa Utara. Jurnal Pesisir Dan Laut Tropis, 2(1), 51-57.

Yuliana, Y., Adiwilaga, E. M., Harris, E., \& Pratiwi, N. T. (2012). Hubungan antara kelimpahan fitoplankton dengan parameter fisik-kimiawi perairan di Teluk Jakarta. Jurnal Akuatika, 3(2), 169-179.

Yuliana, Y. (2015). Distribusi Dan dan Struktur Komunitas Fitoplankton Di di Perairan Jailolo, Halmahera Barat. Jurnal Akuatika, 6(1), 41-48.

(C) 2017 by the authors; licensee Udayana University, Indonesia. This article is an open access article distributed under the terms and conditions of the Creative Commons Attribution license (http://creativecommons.org/licenses/by/3.0/). 